\title{
64. 道路照明における器具配光と明るさ感·視線誘導効果
}

\author{
高嶋 彰 唐沢 宜典 \\ 坂本 正悦 \\ （松下電工株式会社） \\ （松下電器産業株式会社）
}

1.はじめに 道路照明における誘導効果には、照明された路面などによる視覚的誘導効果と照明器具の輝 きによる光学的誘導効果があり、道路照明の重要な要件の 1 つである ${ }^{1}$ 。近年、道路照明器具の小型化、低 コスト化に伴い、従来の凸状のプリズムグローブから平板な強化ガラスが使用されるケースが増えている。 平板ガラスを用いたものは、コンパクト性、配光制 御性に優れる一方で、誘導効果や施設としての明 るさ感に欠ける場合がある。今回、道路照明として の誘導効果、明るさ感を確保するための照明器具 の発光部に関する検討を行ったので報告する。

2. アプローチ 心地よく輝いて感じられる発光部 の要件に関する主钼評価を実施した。

《提示条件》背景輝度; $0,1,2\left[\mathrm{~cd} / \mathrm{m}^{2}\right] /$ 発光部輝 度; $500 \sim 20000\left[\mathrm{~cd} / \mathrm{m}^{2}\right]$ までの 6 段階 / 発光部の 大きさ; $10^{-6} \sim 10^{-4}[\mathrm{sr}]$ まで 5 段階／被験者: 29 〜 51 藏までの正常視力の男女 5 名/評価法: 発光 部が輝いているかどうかの評価を行った。

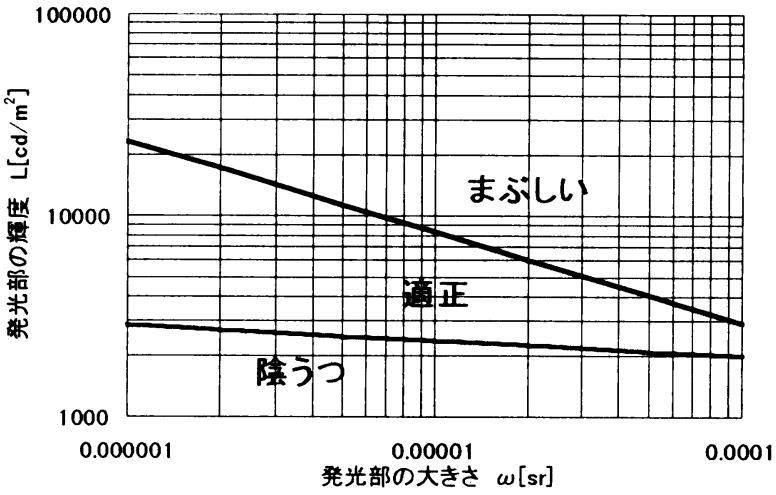

図-1. 輝いて感じられる発光部の大きさ、輝度の関係
3. 結果 図-1に背景輝度が $1.0\left[\mathrm{~cd} / \mathrm{m}^{2}\right]$ の場合の

結果を示す。図中の太線で挟まれた範囲は、5名の被験者の 3 回 づつの合計 15 の回答のうち、60\%以上が「輝いて感じられる」と回 答した範囲を直線回帰によって求めたものである。この結果を式 で表すと次式のようになる。

$-0.08 \log \omega+2.98 \leqq \log L \leqq-0.45 \log \omega+1.67$

$\omega$ : 発光部の立体角 $[\mathrm{sr}] 、 \mathrm{~L}$ : 発光部の輝度 $\left[\mathrm{cd} / \mathrm{m}^{2}\right]$

これによれば、発光面積が大きくなるほど適正な輝度の範囲は 狭くなるので、発光面積を小さくして、輝度を適正な範囲に制御す る方法が考えられる。一方で、照明器具の過剩な輝度はドライバ 一に対するグレアを増加させる原因となるので防止しなければな らない。これについては、別に実施した実験により、発光部の輝 度が高すぎても明るさ感の増加効果は小さく、適正な輝度の範囲 があることが確かめられている。

4. 道路照明器具への適用 実験で得られた知見に基づき製作さ れた適正な誘導効果、明るさ感効果の得られる道路照明器具を 図-2 に示す。この照明器具は、下面に凸状の拡散性のガラスグ ローブを持ち、運転者方向に対してグレアを抑制しながら適正な 光度を与え、視線誘導性を確保している。車道の照明特性にも優 れている(表 1)。

表 1. 車道の照明特性

\begin{tabular}{|l|c|}
\hline 路面輝度 & $1.31 \mathrm{~cd} / \mathrm{m}^{2}$ \\
\hline 総合均斉度 & 0.61 \\
\hline 車線軸均斉度 & 0.73 \\
\hline
\end{tabular}

$(\mathrm{NHT} 220 . \mathrm{L}, \mathrm{H}=10 \mathrm{~m}, \mathrm{~S}=35 \mathrm{~m}, \mathrm{oh}=-1 \mathrm{~m}, \mathrm{M}=0.7)$

【参考文献】1)(社)日本道路協会 編: 道路照明施設設置基準·同解 説(昭和 56 年)

Luminous intensity distributions,Brightness and Optical guidance of Road Lighting Installations ; Akira Takashima,Yoshinori Karasawa,Shoetsu Sakamoto

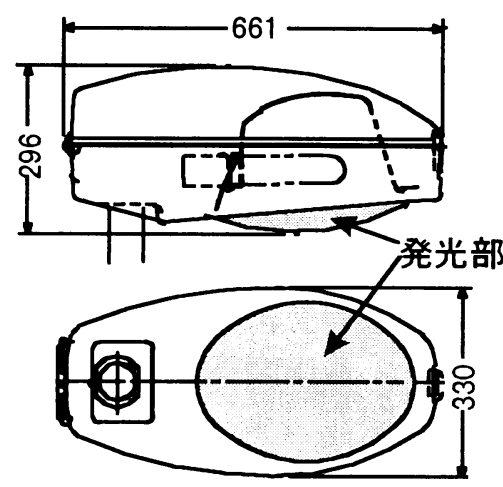

図-2. 誘導性、明るさ感の高い道路照明器具

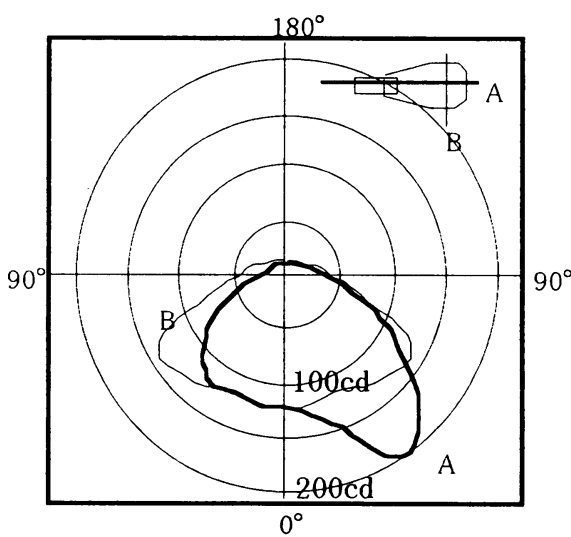

図-3. 照明器具の配光特性 